\section{Kidney Blood Pressure Research}

Kidney Blood Press Res 2012;36:1-9

DOI: 10.1159/000339021

Published online: June 18, 2012

Accepted: April 24, 2012
C 2012 S. Karger AG, Basel www.karger.com/kbr

1420-4096/12/0361-0001\$38.00/0

\title{
Polymorphisms in the Vitamin D Receptor Gene and Parathyroid Hormone Gene in the Development and Progression of Diabetes Mellitus and its Chronic Complications, Diabetic Nephropathy and Non-Diabetic Renal Disease
}

\author{
Marcela Vedralováa Anna Kotrbova-Kozak ${ }^{a}$ Viera Železníkováb Hana Zoubkováa \\ Ivan Rychlíkc Marie Černáa
}

${ }^{a}$ Dept. of General Biology and Genetics, 3rd Faculty of Medicine, Charles University, Prague, Czech Republic, 'bospital Usti nad Labem, Usti nad Labem, Czech Republic, '2nd Dept. of Internal Medicine, 3rd Faculty of Medicine, Prague, Czech Republic

\section{Key Words}

Diabetes • Nephropathy • Parathyroid hormone $\bullet$ Polymorphism • Vitamin D receptor

\begin{abstract}
Background: We chose to study polymorphisms of vitamin D receptor gene (VDR) and parathyroid hormone genes (PTH), whose protein products significantly affect calciumphosphate metabolism in kidneys and are implicated in the pathogenesis of diabetes, which may also involve kidney damage. Methods: Distribution of genotypes of four polymorphisms in VDR gene i.e TaqI (rs731236), BsmI (rs1544410) ApaI (rs7975232), FokI (rs2228570) and two polymorphisms of PTH gene, i.e. DraII (rs6256), BstBI (rs6264), were studied using PCRRFLP. Examined groups consisted of 147 patients with diabetes (DM), 47 patients with nondiabetic renal disease (NDRD), 132 patients with diabetic nephropathy (DN) and 118 healthy subjects. Conclusion: Comparison of DN group and healthy subjects identified statistically significant difference for the FokI polymorphism in VDR gene $(P<10-4)$ and also for the BstBI polymorphism in PTH gene $(P=0,023)$. Differences in DraII polymorphism distribution in PTH gene were statistically significant in each group of patients compared to healthy subjects. In DN patients, the BBFFAATt combination of VDR gene was more frequent than in healthy subjects $(P=0,046)$, and the BbFFAaTt variant was more frequent than in DM2 patients $(P=0,018)$. The BBDD haplotype of PTH gene seems to be a predisposing factor for diabetes itself $(P=0,019)$.
\end{abstract}




\section{Kidney
Blood Pressure Research}

Kidney Blood Press Res 2012;36:1-9

\begin{tabular}{l|l}
\hline DOI: $10.1159 / 000339021$ & C 2012 S. Karger AG, Basel
\end{tabular}

Published online: June 18, 2012

www.karger.com/kbr

Vedralová/Kotrbova-Kozak/Železníková et al.: VDR and PTH Polymorphisms in Diabetes and Complications

\section{Introduction}

It is generally accepted that, besides regulation of bone remodeling, the action of vitamin $\mathrm{D}$ include maintenance of mineral homeostasis by regulation of calcium absorption in the gut and its reabsorption by the kidney. Many noncalcemic functions of vitamin D involve induction of differentiation in peripheral blood mononuclear cells, antiproliferative effects in many cancers and immunosuppression. Particularly important is its protective role in autoimmune disorders, like type I diabetes and vitamin D also acts as a necessary adjunct for insulin secretion [1-6]. A role of vitamin D has been suggested in other diseases, like cancer, diabetes and cardiovascular diseases [7].

The main sources of vitamin D are ergocalciferol (D2) and cholecalciferol (D3), found in dietary sources and supplements, and indigenous cholecalciferol produced from 7 dehydrocholesterol in the skin. Both these compounds are hydroxylated in the liver to form 25-hydroxyvitamin $\mathrm{D}[25(\mathrm{OH}) \mathrm{D}]$, which is the major circulating metabolite precursor to the hormonally active form, 1,25-dihydroxyvitamin $\mathrm{D}\left[1,25(\mathrm{OH})_{2} \mathrm{D}\right]$. Hydroxylation of $25(\mathrm{OH}) \mathrm{D}$ intermediate, stimulated by parathyroid hormone, produces the hormonally active metabolite $1,25(\mathrm{OH})_{2} \mathrm{D}$, mainly in the kidney $[8,9]$.

As vitamin D (1,25-dihydroxyvitamin D3) receptor (VDR) gene is expressed in a large number of tissues, it is not surprising that ligand-activated VDR modulates expression of multiple target genes. The VDR gene (GenBank acession no. HGNC ID. 12679) is located on chromosome 12q12-q14 and harbors 14 exons, 6 of which reside within the 5'untranslated region. Allelic polymorphism of VDR gene includes $\mathrm{B} / \mathrm{b}$ and $\mathrm{A} / \mathrm{a}$ alleles present in intron 8 and $\mathrm{T} / \mathrm{t}$ alleles present in exon 9 . The $\mathrm{F} / \mathrm{f}$ polymorphism, in the codon initiating translation and leading to serious protein insufficiency, has been also described. A number of common chronic disorders of inflammatory, infective, and autoimmune etiologies, including both type 1 and type 2 diabetes and colorectal adenoma, have been shown associated with specific polymorphisms of the vitamin D receptor gene. For example, patients with type 1 diabetes showed slightly increased prevalence of "ff" VDR genotype [10]. Individuals with the BB genotype can remain longer on hemodialysis before they need parathyroidectomy [11].

Parathyroid hormone (PTH) belongs to the most significant regulators of calcium and phosphate metabolism. Located on chromosome 11p15.3-p15.1, PTH gene (GenBank accession no. HGNC ID. 9606) encodes pre-pro-parathyroid hormone, which is consecutively adjusted in functional protein. Allelic polymorphism of the PTH gene includes B/b and D/d alleles present in exons. It is assumed that DD genotype is associated with lower plasmatic levels of parathyroid hormone [12].

The aim of this study was to investigate four polymorphisms of the VDR gene and two polymorphisms of the PTH gene with respect to development and progression of diabetes mellitus (DM) and its chronic complications in patients coming from the Central Bohemian population of the Czech Republic.

\section{Materials and Methods}

\section{Subjects}

Patients were divided into four groups, the DM1 group of 54 patients with type 1 diabetes without nephropathy, the DM2 group of 116 patients with type 2 diabetes without nephropathy, the DN group of 132 diabetic patients with diabetic nephropathy, and the NDRD group of 47 diabetic patients with nondiabetic renal disease. The control group was represented by 118 healthy blood donors without any signs of nephropathy and diabetes. The study was approved by the Ethical Committee of the Third Faculty of Medicine, Charles University in Prague. Written informed consent was obtained from all subjects. The diagnosis of diabetes was made according to published criteria [13].

Criteria for the definitions of nephropathy type were applied according to clinical - laboratory findings (Table 1). The group of DN was formed by patients fulfilling the following criteria: chronic kidney disease (CKD) stage 2-4, duration of DM as minimum as 10 years, 24-hour proteinuria $>0,5 \mathrm{~g}$, normal kidney size 


\section{Kidney \\ Blood Pressure Research}

Kidney Blood Press Res 2012;36:1-9

\begin{tabular}{l|l}
\hline DOI: $10.1159 / 000339021$ & (C) 2012 S. Karger AG, Basel
\end{tabular}

Published online: June 18, 2012

Table 1: Background data for group of patients and healthy subjects

\begin{tabular}{|c|c|c|c|c|c|}
\hline group & NDRD & DN & DM 1 & DM 2 & $\begin{array}{l}\text { healthy } \\
\text { subjects }\end{array}$ \\
\hline number in group & 47 & 132 & 54 & 116 & 118 \\
\hline gender & 19 female & 57 female & 22 female & 54 female & 67 female \\
\hline & 28 male & 75 male & 32 male & 92 male & 51 male \\
\hline $\begin{array}{l}\text { age (years) } \\
\text { arterial }\end{array}$ & $80 \pm 1.16$ & $70 \pm 13$ & $41 \pm 16.9$ & $67 \pm 12.44$ & $45 \pm 7.31$ \\
\hline hypertension & $77 \%$ yes & $79.79 \%$ yes & $14.2 \%$ yes & $56 \%$ yes & no \\
\hline $\begin{array}{l}\text { diabetic } \\
\text { retinopathy }\end{array}$ & $13 \%$ yes & $82.68 \%$ yes & $14.2 \%$ yes & $21 \%$ yes & no \\
\hline U-Alb (g/24) & $0.08 \pm 0.12$ & $0.82 \pm 1.16$ & $0.004 \pm 0.004$ & $0.04 \pm 0.15$ & $<0.15 \mathrm{~g} / 24$ \\
\hline DU-Prot (g/24) & $0.30 \pm 0.27$ & $2.80 \pm 3.14$ & $0.01 \pm 0.001$ & $0.12 \pm 0.39$ & $<0.03 \mathrm{~g} / 24$ \\
\hline $\mathrm{S}-\mathrm{Cr}(\mu \mathrm{mol} / \mathrm{l})$ & $162 \pm 44.6$ & $308 \pm 227.12$ & $90.42 \pm 15.51$ & $112.94 \pm 60.72$ & $\begin{array}{l}44-110 ; 44-104 \\
\text { males females }\end{array}$ \\
\hline HbA1C (\%) & $7.8 \pm 1.89$ & $7.21 \pm 2.13$ & $6.27 \pm 0.77$ & $6.09 \pm 2.01$ & $2.8-4 \%$ \\
\hline
\end{tabular}

$\mathrm{U}-\mathrm{Alb}=$ Albuminuria, DU-Prot.=amount of urinary protein in 24 hours, $\mathrm{S}-\mathrm{Cr}=$ Serum creatine, HbA1C=glycated hemoglobin.

by ultrasound examination performed in six months, and the presence of diabetic retinopathy of any grade. The criteria for NDRD patients were the following: CKD stage 2-4, absence of proteinuria and increased microalbuminuria, duration of DM as minimum as 10 years, reduced kidney size on ultrasound examination performed in six months, and the absence of diabetic retinopathy. DN was classified according to previously published criteria [14].

Methods: Principles of the molecular genetic procedure

Genomic DNA was extracted from peripheral blood leucocytes using salting out method described previously [15]. Four VDR polymorphisms were identified by the polymerase chain reaction followed by restriction length polymorphism (PCR/RFLP) method. All PCR primers were designed based on sequences published previously by Israni et al. [16]. The PCR was carried out in a final volume of $50 \mu$ l containing 20$50 \mathrm{ng} / \mu \mathrm{l}$ DNA templates, $\mathrm{NH}_{4}\left(\mathrm{SO}_{4}\right) 2,1,5 \mathrm{mM} \mathrm{MgCl}_{2}, 2 \mathrm{mM}$ dNTP and reaction buffer (all from Fermentas, Canada), $100 \mathrm{pmol} / \mathrm{ul}$ of each primer, and $1 \mathrm{U}$ Taq DNA polymerase. The PCR program was as follows: $94^{\circ} \mathrm{C}$ for 5 minutes ( $1 \mathrm{cycle}$ ), $94^{\circ} \mathrm{C}$ for $30 \mathrm{sec}, 66^{\circ} \mathrm{C}$ for $30 \mathrm{sec}$, and $72^{\circ} \mathrm{C}$ for $30 \mathrm{sec}$ ( $35 \mathrm{cycles}$ ).

The forward and reverse primers used to amplify locus with FokI polymorphism (rs222857) in exon 2 were 5'AGCTGGCCCTGGCACTGACTC3' and 5'ATGGAAACACCTTGCTTCTTCTCCCTC3', respectively. Upon digest with the enzyme, the PCR product with FokI polymorphism produced $196 \mathrm{bp}$ plus $69 \mathrm{bp}$ fragments. ApaI polymorphism (rs7975232) in intron 8 and TaqI polymorphism (rs731236) in exon 9 were studied by amplifying a 740 bp long fragment using forward 5'CAGAGCATGGACAGGGAGCAA3' and reverse 5'GCAACTCCTCATGGCTGAGGTCTC3' primers. Amplicons positive for ApaI polymorphism were split by the enzyme to $520 \mathrm{bp}$ and $220 \mathrm{bp}$ fragments. When treated with TaqI, the presence of enzyme target sites resulted in fragments of $290 \mathrm{bp}, 245 \mathrm{bp}$ and $250 \mathrm{bp}$. The forward and reverse primers for the BsmI polymorphism ( $r s 1544410$ ) in intron 8 were 5'CAACCAAGACTACAAGTACCGCGTCAGTGA3' and 5'AACCAGCGGGAAGAGGTCAAGGG3', respectively, and annealing at $65^{\circ} \mathrm{C}$ was used. The amplicon harboring $B s m I$ polymorphism was cut by BsmI to 650 bp plus 175 bp fragments.

Forward 5'CATTCTGTGTACTATAGTTTG'3 and reverse 5'GAGCTTTGAATTAGCAGCATG3' primers used to amplify intron 2 and exon 3 of the PTH gene were designed based on the report by Gohda et al. [12]. Reaction conditions for amplification of locus harboring BstBI (rs6254) and DraII ( rs6256) polymorphisms were the same as described above, except for primer annealing at $52^{\circ} \mathrm{C}$. The PCR product was $600 \mathrm{bp}$ long and cut by BstBI endonuclease to fragments of 387 bp plus 213 bp. DraII endonuclease generated 420 bp plus $180 \mathrm{bp}$ fragments. All digested products were separated on $3 \%$ agarose gel and were visualized by GelRed (Biotium, USA) staining.

Principles of the biochemical procedure

Albumin detection in urine: Microalbumin content was assessed by using a PEG enhanced immunoturbidimetric assay. To this end, albumin of the sample was allowed to react with specific antiserum to form a precipitate. The precipitate intensity was measured turbidimetrically at $340 \mathrm{~nm}$ and the albumin concentration was determined by using the standard curve obtained by the same method with serial dilutions of human albumin standard.

Protein detection in urine: Protein content in urine was assessed using pyrogallol red colorimetric method. In acidic environment, pyrogallol red forms a blue-colored complex with molybdate and proteins. The absorbance of the complex was read at 596/694 nm and the protein concentration was determined by using the standard curve obtained by the same method with serial dilutions of human albumin standard. 


\section{Kidney Blood Pressure Research}

Kidney Blood Press Res 2012;36:1-9

Table 2: Genotype and allele frequencies of FokI polymorphism

\begin{tabular}{lllllll}
\hline \multicolumn{2}{l}{$\begin{array}{l}\text { VDR genotype/ } \\
\text { allele }\end{array}$} & $\begin{array}{l}\text { NDRD } \\
\text { n (frequency) }\end{array}$ & $\begin{array}{l}\text { DM 1 } \\
\text { n (frequency) }\end{array}$ & $\begin{array}{l}\text { DM 2 } \\
\text { n (frequency) }\end{array}$ & $\begin{array}{l}\text { DN } \\
\text { n= (frequency) }\end{array}$ & $\begin{array}{l}\text { healthy subjects } \\
\text { n (frequency) }\end{array}$ \\
\hline FokI & ff & $3(0.064)$ & $10(0.185)$ & $18(0.155)$ & $11(0.083)$ & $12(0.106)$ \\
& Ff & $28(0.596)$ & $25(0.463)$ & $60(0.517)$ & $58(0.439)$ & $76(0.673)$ \\
& FF & $16(0.340)$ & $19(0.352)$ & $38(0.328)$ & $63(0.477)$ & $25(0.221)$ \\
P-value & & 0.25 & $\mathbf{0 . 0 3 4}$ & 0.057 & $\mathbf{1 0}^{-4}$ & \\
& f & $34(0.362)$ & $45(0.416)$ & $96(0.438)$ & $80(0.303)$ & $100(0.442)$ \\
& F & $60(0.638)$ & $63(0.584)$ & $136(0.586)$ & $184(0.697)$ & $126(0.558)$ \\
P-value & & 0.214 & 0.724 & 0.571 & $\mathbf{0 . 0 0 2}$ & \\
OR & 1.401 & 0.900 & 1.124 & 1.825 & \\
$95 \%$ CI & $0.958-1.267$ & $0.566-1.431$ & $0.776-1.628$ & $1.259-2.646$ & \\
\hline
\end{tabular}

OR-odds ratio, $95 \% \mathrm{CI}$ - confidence interval, $\mathrm{P}$ values $<0.05$ are shown in bold. Genotype and allele frequencies of the FokI polymorphism in each group of patients were compared with control group. B (Power analysis) = 0.95 .

Table 3: Genotype and allele frequencies of BstBI polymorphism

\begin{tabular}{|c|c|c|c|c|c|c|}
\hline \multicolumn{2}{|c|}{$\begin{array}{l}\text { VDR genotype/ } \\
\text { allele }\end{array}$} & $\begin{array}{l}\text { NDRD } \\
\mathrm{N} \text { (frequency) }\end{array}$ & $\begin{array}{l}\text { DM } 1 \\
\mathrm{~N} \text { (frequency) }\end{array}$ & $\begin{array}{l}\text { DM } 2 \\
\mathrm{~N} \text { (frequency) }\end{array}$ & $\begin{array}{l}\text { DN } \\
\mathrm{N} \text { (frequency) }\end{array}$ & $\begin{array}{l}\text { healthy subjects } \\
\mathrm{N} \text { (frequency) }\end{array}$ \\
\hline \multirow[t]{3}{*}{ BstBI } & $\mathrm{bb}$ & $5(0.111)$ & $7(0.137)$ & $14(0.135)$ & $12(0.106)$ & $20(0.241)$ \\
\hline & $\mathrm{Bb}$ & $25(0.556)$ & $26(0.467)$ & $47(0.452)$ & $46(0.407)$ & $33(0.398)$ \\
\hline & $\mathrm{BB}$ & $15(0.333)$ & $18(0.354)$ & $43(0.413)$ & $55(0.487)$ & $30(0.361)$ \\
\hline \multicolumn{2}{|c|}{$\mathrm{P}$ - value } & 0.123 & 0.620 & 0.173 & 0.023 & \\
\hline & $\mathrm{b}$ & $35(0.338)$ & $40(0.392)$ & $75(0.360)$ & $70(0.309)$ & $73(0.439)$ \\
\hline & B & $55(0.662)$ & $62(0.608)$ & $133(0.640)$ & $156(0.691)$ & $93(0.561)$ \\
\hline \multicolumn{2}{|c|}{$\mathrm{P}$ - value } & 0.508 & 0.524 & 0.136 & 0.011 & \\
\hline \multicolumn{2}{|c|}{ OR } & 1.233 & 0.822 & 1.392 & 1.749 & \\
\hline \multicolumn{2}{|c|}{$95 \% \mathrm{CI}$} & $0.731-2.081$ & $0.4975-1.358$ & $0.917-2.113$ & $1.153-2.653$ & \\
\hline
\end{tabular}

OR - odds ratio, $95 \% \mathrm{CI}$ - confidence interval, $\mathrm{P}$ values $<0.05$ are shown in bold. Genotype and allele frequencies of the BstBI polymorphism in each group of patients were compared with control group. $\beta$ (Power analysis) $=0.75$.

Statistical Analysis

The statistical analysis was performed using software GraphPad Prism 5. 04. Comparison between groups was determined with Fisher's exact two-tailed test. Differences among groups were considered statistically significant if $\mathrm{P}<0,05$. Odds ratios (ORs) were calculated with $95 \%$ confidence interval (CI). It was performed Power analysis $(\beta)$. As the numbers of subjects in DM1 and NDRD groups were small, the Power analysis $(\beta)$ was conducted only for DN, DM2 and control group ( $\beta$ values shown for statistically significant polymorphism distributions).

\section{Results}

By using the PCR-RFLP methods we analyzed four polymorphisms in VDR gene and two polymorphisms in PTH gene. SNPs in VDR gene included FokI (T/C) in exon 2, TaqI (T/C) in exon 9, BsmI (G/A) and ApaI (G/T) polymorphisms in intron 8. SNPs for PTH gene included BstBI (G/A) in intron 2 and DraII (C/A) polymorphism in exon 3. For each of these SNPs, we compared frequencies of genotypes and alleles in each group of patients with controls. Frequencies of FokI polymorphism are shown in Table 2. We found that $\mathrm{F}$ allele presented highter risk of DN $(\mathrm{P}=0,002, \mathrm{OR}=1,825,95 \% \mathrm{CI} 1,259-2,646)$. When individual genotype were compared distribution of FokI VDR gene polymorphism was significantly different with a higher frequency of $\mathrm{F}$ and lower frequency of $\mathrm{f}$ in patients with $\mathrm{DN}(\mathrm{P}=0,002, \mathrm{OR}=1,825$, 95\%CI 1, 259-2,646) compared to controls.

There were no differences in the genotype frequencies of the BsmI, ApaI and TaqI polymorphisms between patient groups and healthy subjects (data not shown in tables.).

Frequencies of BstBI polymorphism PTH gene are shown in Table 3. The distribution of genotype frequencies of $B s t \mathrm{BI}$ polymorphism differed significantly between DN and healthy subjects $(\mathrm{P}=0,023)$. The $\mathrm{B}$ allele occured more frequently in $\mathrm{DN}$ patients $(\mathrm{P}=0,011$, OR 1,749, 95\%CI 1,153-2,653). The distribution of Drall polymorphism is shown in Table 4. Differences in DraII polymorphism distribution were statistically significant in each group of patients compared to healthy subjects. 


\section{Kidney Blood Pressure Research}

Kidney Blood Press Res 2012;36:1-9

DOI: $10.1159 / 000339021$

Published online: June 18, 2012

(c) 2012 S. Karger AG, Basel www.karger.com/kbr

Table 4: Genotype and allele frequencies of DraII polymorphism

\begin{tabular}{|c|c|c|c|c|c|c|}
\hline \multicolumn{2}{|c|}{$\begin{array}{l}\text { PTH genotype/ } \\
\text { allele }\end{array}$} & $\begin{array}{l}\text { NDRD } \\
\text { N (frequency) }\end{array}$ & $\begin{array}{l}\text { DM } 1 \\
\text { N (frequency) }\end{array}$ & $\begin{array}{l}\text { DM } 2 \\
\text { N (frequency) }\end{array}$ & $\begin{array}{l}\mathrm{DN} \\
\mathrm{N} \text { (frequency) }\end{array}$ & $\begin{array}{l}\text { healthy subjects } \\
\mathrm{N} \text { (frequency) }\end{array}$ \\
\hline \multirow[t]{3}{*}{ DralI } & dd & $1(0.022)$ & $2(0.039)$ & $5(0.049)$ & $1(0.009)$ & $1(0.0011)$ \\
\hline & Dd & $15(0.326)$ & $14(0.269)$ & $32(0.311)$ & $42(0.375)$ & $56(0.636)$ \\
\hline & DD & $30(0.652)$ & $36(0.692)$ & $66(0.641)$ & $69(0.616)$ & $31(0.352)$ \\
\hline \multirow{3}{*}{ P-value } & & 0.003 & $10^{-4}$ & $10^{-4}$ & $10^{-3}$ & \\
\hline & d & $17(0.185)$ & $18(0.173)$ & $42(0.204)$ & $44(0.196)$ & $58(0.329)$ \\
\hline & D & $75(0.815)$ & $86(0.827)$ & $164(0.796)$ & $180(0.804)$ & $118(0.671)$ \\
\hline \multicolumn{2}{|c|}{ P-value } & 0.015 & 0.005 & 0.007 & 0.003 & \\
\hline \multicolumn{2}{|c|}{$\mathrm{OR}$} & 2.168 & 0.426 & 1.919 & 2.011 & \\
\hline \multicolumn{2}{|c|}{$95 \% \mathrm{CI}$} & $1.174-4.004$ & $0.234-0.7740$ & $1.209-3.047$ & $1.275-3.171$ & \\
\hline
\end{tabular}

Table 5: Associations of VDR BsmI-FokI-ApaI-TaqI and PTH BstBI-DraII haplotypes between DN, DM2 and healthy subjects

\begin{tabular}{|c|c|c|c|}
\hline Haplotype & $\begin{array}{l}\text { DN vs. healthy subjects } \\
\text { P value; OR (95\% CI) }\end{array}$ & $\begin{array}{l}\text { DM2 vs. healthy subjects } \\
\text { P value; OR (95\% } \% \text { CI) }\end{array}$ & $\begin{array}{l}\text { DN vs DM2 } \\
\text { P value; OR }(95 \% \mathrm{CI})\end{array}$ \\
\hline \multicolumn{4}{|l|}{ VDR gene } \\
\hline BBFFAATt & $\mathbf{0 . 0 4 6} ; 0.935(0.890-0.983)$ & no significance & no significance \\
\hline BbFFAaTt & no significance & no significance & $\mathbf{0 . 0 1 8} ; 2.575(1.119-5.923)$ \\
\hline \multicolumn{4}{|l|}{ PTH gene } \\
\hline bbDd & $10^{-4} ; 2.623(1.105-6.229)$ & $\mathbf{1 0} \mathbf{- 4} ; 0.080(0.018-0.361)$ & no significance \\
\hline BBDD & $\mathbf{0 . 0 0 2} ; 3.380(1.457-7.841)$ & $\mathbf{0 . 0 1 9} ; 2.623(1.105-6.229)$ & no significance \\
\hline
\end{tabular}

We were particularly interested in effects the combinations of VDR or PTH genotypes would exert on development of diabetic complications (Table 5). Analyses of possible VDR combination within the DN group revealed the frequency of a certain haplotypes statistically different from healthy subjects. It was BBFFAATt $(\mathrm{OR}=0,935 ; 95 \% \mathrm{CI}=0,890-0,983)$, carried by 7 individuals of DN group (6,5\%), but absent in the group of healthy subjects. In contrast, comparison of VDR haplotypes present within DM2 and the control group did not show any significant differences. Assessment of VDR haplotype combinations in DN and DM2 groups identified genotype BbFFAaTt (OR=2,575; 95\% CI=1,119-5,593) carried by 21 individuals of DN group $(19,4 \%)$ and 9 individuals of DM2 group $(8,6 \%)$ as displaying statistically different abundance in these two groups.

The analyses of PTH genotype frequencies were performed with respect to its alleles $\mathrm{B} / \mathrm{b}$ and $\mathrm{D} / \mathrm{d}$. The frequency of two haplotype sets was proven statistically different between $\mathrm{DN}$ and the control groups. These were bbDd (OR=0,037; $95 \% \mathrm{CI}=0,005-0,0285)$ and BBDD $(\mathrm{OR}=3,380 ; 95 \% \mathrm{CI}=1,457-7,841)$. While bbDb was found in a single carrier of DN group $(0,9 \%)$, it was identified with 16 individuals of the control group (19,8\%). Although these data suggest that bbDb confers a protective role against diabetes-related complications, relatively high frequency of BBDD within DN group ( $\mathrm{N}=30 ; 27 \%)$ as compared to the control group $(\mathrm{N}=8 ; 0,9 \%)$ and $\mathrm{OR}>1$ signify a predisposition factor for diabetic nephropathy.

Comparison of PTH haplotypes between DM2 and healthy subjects identified that they are significantly different by the same combinations. Haplotype bbDd showed OR=0,080 and $95 \% \mathrm{CI}=0,018-0,361$ and BBDD was characterized by $\mathrm{OR}=2,623$ and $95 \% \mathrm{CI}=1,105-6,229$. Haplotype bbDd was carried by 2 and 16 individuals from DM2 group $(1,9 \%)$ and control group $(19,8 \%)$, respectively, thereby suggesting negative association of this genotype with type 2 diabetes. In contrast $\mathrm{OR}>1$ and high frequency of BBDD within DM2 group ( $\mathrm{N}=23$; $22,3 \%)$ as compared to control group ( $\mathrm{N}=8 ; 9,9 \%)$ suggest positive correlation of this genotype with type 2 diabetes. Comparison of PTH haplotypes of DN and DM2 did not reveal any statistically significant prevalence. 


\section{Kidney
Blood Pressure Research}

Kidney Blood Press Res 2012;36:1-9

\begin{tabular}{l|l}
\hline DOI: $10.1159 / 000339021$ & C 2012 S. Karger AG, Basel
\end{tabular}

Published online: June 18, 2012

www.karger.com/kbr

Vedralová/Kotrbova-Kozak/Železníková et al.: VDR and PTH Polymorphisms in Diabetes and Complications

\section{Discussion}

In the present study, we examined the role that selected variants in the VDR and PTH genes would play in susceptibility of individuals to diabetes mellitus type 1 and 2, diabetic nephropathy and non-diabetic renal disease in Czech population. The progression of renal disease of any origin is closely related to the development of calcium and phosphorus metabolism disorders. It has been well established that reduction of phosphate excretion and production of calcitriol stimulate the activity of the parathyroid gland [17]. Despite of well known fact that an increase in parathyroid hormone secretion is less pronounced among patients with diabetic nephropathy, the knowledge about the nature of renal bone disease is incomplete. Currently, the link between calcium deposition in the vessel walls and accelerated development of atherosclerosis is emphasized and a new concept of renal bone and vascular disease is being introduced $[18,19]$.

Diabetes mellitus is considered as a cause of decreasing incidence of bone disease resulting of secondary hyperparathyroidism on one side, and, on the other side, as one of the cause of increasing prevalence of dynamic forms of renal osteopathy. The reasons for this epidemiology pattern are not entirely clear. Early papers indicated that increased excretion of phosphorus leads to lower stimulation of the parathyroid glands, while later reports pointed out the fact that glycation of parathyroid hormone results in the reduction of its activity or that glycation of PTH-prohormone reduces circulating levels of PTH [20].

Typical changes of calcium and phosphorus metabolism are manifested during the progression of chronic kidney disease (CKD) of any origin with typical laboratory findings of secondary hyperparathyroidism. According to recent studies, changes of calcium and phosphorus metabolism in CKD may be due to genetic background and thus the attention of researcher is also focused on investigation of polymorphisms of vitamin $D$ receptor gene (VDR and PTH) [12, 21-23].

Here we report that, compared to healthy subjects, the F allele of VDR gene is prevailing in DN individuals from Czech population. In a cohort of Caucasians with C-peptide-negative type 1 diabetes, a novel association between the functional FokI VDR polymorphism and severe diabetic retinopathy was observed, especially among young subjects with fewer than 25 years of diabetes duration [24]. Association analysis of Notch pathway signaling genes in diabetic nephropathy show that common variants are not strongly associated with diabetic nephropathy in type 1 diabetes among white individuals [25]. In hemodialysis patients with transferrin saturation $<20 \%$, the $\mathrm{F}$ allele was more frequent than in hemodialysis patients with transferrin saturation $>20 \%$. This relationship may provide a link between VDR alleles and levels of circulation iron and nutritional markers, which are highly predictive variables of cardiovascular morbidity and mortality in hemodialysis patients [26]. FokI polymorphisms of the VDR gene may determine parathyroid response in patients with chronic renal failure [27]. Our results confirm this observation. Moreover, we found increased frequency of $\mathrm{F}$ allele for FokI polymorphism in DN patients.

We did not detect significant association of BsmI, ApaI and TaqI polymorphisms with either patient group. It should be noted that some studies suggest weak associations of corresponding single nucleotide polymorphisms in VDR alleles or haplotypes with type 1 and type 2 DM $[28,29]$. However, while their haplotypes were reported as associated with type 1 diabetes in the German and Taiwan [30,31] population, recent data from a broad familial study did not prove such association in populations from UK, Finland, Norway and Romania statistically significant [32, 33].

We were particularly interested in effects the combinations of VDR or PTH genotypes would exert on development of diabetic complications. The results of this study demonstrated that combinations BBDD genotype (PTH gene) seems to be predisposing factor for development of type 1 diabetes, but not for development of diabetic nephropathy. The bbDd genotype seems to have protective role in development of diabetes and its complications. 


\section{Kidney \\ Blood Pressure Research}

Kidney Blood Press Res 2012;36:1-9

\begin{tabular}{l|l}
\hline DOI: $10.1159 / 000339021$ & (C) 2012 S. Karger AG, Basel
\end{tabular}

Published online: June 18, 2012

www.karger.com/kbr

Vedralová/Kotrbova-Kozak/Železníková et al.: VDR and PTH Polymorphisms in Diabetes and Complications

The occurrence of PTH genotypes and of respective polymorphisms of $\mathrm{B} / \mathrm{b}$ and $\mathrm{D} / \mathrm{d}$ was previously inspected with respect to incidence hyperparathyreosis [12].

Previous reports addressing frequencies of genotype combinations with respect to the above described polymorphisms provided information about the associations of particular genotype(s) with type 1 diabetes. Genotype BBAAtt and corresponding haplotype BAt are considered disease risk factors in Croation and German populations, respectively [34, 30]. Isrami et al. reported the haplotype BFAt as markedly associated with type 1 diabetes [16]. Furthermore, Dogan et al. reported haplotype baT as risk factor of lung tumor development and Gunes et al. found haplotype bAT associated with the incidence of periondontitis [35, 36]. Physiological studies in human suggest that allelic variations in the VDR gene modulate $\beta$-cell function. It was first reported in Bangladeshi subjects, that ApaI, BsmI and TaqI single nucleotide polymorphisms influence insulin secretion in response to an oral glucose tolerance test [37]. Our data signify that the genotype BBFFAATt (VDR gene) is to be considered the risk factor of diabetes-related complications, particularly of diabetic nephropathy.

A major advantage of the study design is the comparability between patients with and without kidney complications. Patients with kidney complications were divided according diabetes type into separated groups. A study composed of subjects all of the same ethnicity helps minimize heterogeneity, exposure to environmental differences and population substructure. Testing more polymorphisms of one gene should bring more precise data on genetic predisposition.

There are a number of limitations of this study. A family history of diabetes and kidney disease in the control group of healthy blood donor is not known. We could not exclude that some type 2 diabetic patients without nephropathy will develop this complication later in the course of the disease even if they had no retinopathy or microalbuminuria at the time of screening. A greater number of subjects may also be necessary to further confirm these results.

\section{Disclosure statement}

The authors of this manuscript have no conflict of interests.

\section{Acknowledgments}

This work was partially funded by the Research program SVV-264702 of Charles University in Prague and A.K.K. gratefully acknowledges support of the Charles University through University Research Centre program UNCE 204015.

\section{References}

1 Chen S, Sims GP, Chen XX, Gu YY, Chen S, Lipsky PE: Modulator Effects of 1,25 Dihydroxyvitamin D3 on Human B Cell Differentiation. J Immunol 2007;179:1634-1647.

-2 Lemire JM, Adams JS, Saka R, Jordan SC: 1 alpha,25-dihydroxyvitamin D3 suppresses proliferation and immunoglobulin production by normal human peripheral blood mononuclear cells. J Clin Invest 1984;74:657-661.

3 Mathieu Ch, van Ettena E, Decallonnea B, Guiliettia A, Gysemansa C, Bouillona R, Overbergh L: Vitamin D and 1,25 - dihydroxyvitamin D3 as modulators in the immune system. J Steroid Biochem Molec Biol 2004;89-90:449-452.

4 Fletcher JM, Basdeo SA, Allen AC, Dunne PJ: Therapeutic use of vitamin D and its analogues in autoimmunity. Recent Pat Inflamm Allergy Drug Discov 2012;6:22-34

5 Mora JR, Iwata M, von Andrian UH: Vitamin effects on the immune system: vitamins A and D take centre stage. Nature Rev Immunol 2008;8:685-698. 


\section{Kidney \\ Blood Pressure Research}

Kidney Blood Press Res 2012;36:1-9

\begin{tabular}{l|l} 
DOI: $10.1159 / 000339021$ & (C) 2012 S. Karger AG, Basel
\end{tabular}

Published online: June 18, 2012

www.karger.com/kbr

Vedralová/Kotrbova-Kozak/Železníková et al.: VDR and PTH Polymorphisms in Diabetes and Complications

6 Zeitz U, Weber K, Soegiarto DW, Wolf E, Balling R, Erben R: Impaired insulin secretory capacity in mice lacking a functional vitamin D receptor. FASEB J 2003; 17: 509-511.

7 Valdivielso JM, Fernandez E: Vitamin D receptor polymorphisms and diseases. Int J Clin Chem 2006;371:112.

8 Holick MF: Vitamin D and Bone Health. J Nutr 1996;126:1159-1164.

-9 Holick MF: Sunlight and vitamin D for bone health and prevention of autoimmune diseases, cancers, and cardiovascular disease. Am J Clin Nutr 2004;80:1678-1688.

-10 Capoluongo E, Pitocco D, Concolino P, Santonocito C, Di Stasio E, d'Onofrio G, Manto A, Giardina B, Ghirlanda G, Ameglio F, Zuppi C: Slight association between type 1 diabetes and "ff" VDR FokI genotype in patients from the Italian Lazio Region. Lack of association with diabetes complications. Clin Biochem 2006;39:888-892.

-11 Borras M, Torregrossa V, Oliveras A, Almirall J, Ma PAZ M, Betriu A, Martin M, Muray S, Fibla J, Fernández E: BB genotype of the vitamin $D$ receptor gene polymorphism postpones parathyroidectomy in hemodialysis patients. J Nephrol 2003;16:116-120.

12 Gohda T, Shou I, Fukui M, Funabiki K, Horikoshi S, Shirato S, Tomino Y: Parathyroid Hormone, Gene Polymorphism and Secondary Hyperparathyroidism in Hemodialysis Patients. Am J Kidney Dis 2002;39:1255-1260.

13 World Health Organisation Definition:Diagnosis and Classification of Diabetes Mellitus and its Complication. Report of a WHO Consultation, Part 1: Diagnosis and Classification of Diabetes Mellitus. Geneva 1999.

14 NKF-KDOQI (National Kidney Foundation-Kidney Disease Outcome Quality Initiative). Clinical practice guidelines for chronic kidney disease: Evaluation, classification and stratification. Part 5 evaluation of laboratory measurement for clinical assessment of kidney disease. Am J Kidney Dis 2002;39:76-110.

-15 Miller S, Dyker D, Poleshy G: Simple salting-out procedure for extracting DNA from human nucleated cells. Nucl Acid Res 1988;16:1215.

-16 Israni N, Goswami R, Kumar A, Rani R: Interaction of Vitamin D Receptor with HLA DRB1 0301 in Type 1 Diabetes Patients from North India. PLoS ONE 2009;4:8023.

17 Lorenzo Sellares V, Torregrosa V: Changes in mineral metabolism in stage 3, 4, and 5 chronic kidney disease (not on dialysis). Nefrologia 2008;28:67-78.

18 Foley RN, Parfrey PS, Sarnak MJ: Epidemiology of cardiovascular disease in chronic renal disease. J Am Soc Nephrol 1998;9:S16-23.

19 London GM, Drueke TB: Atherosclerosis and arteriosclerosis in chronic renal failure. Kidney Int 1997;51:1678-1695.

-20 Yamamoto T, Ozono K, Miyauchi A, Kasayama S, Kojima Y, Shima M, Okada S: Role of advanced glycation end products in adynamic bone disease in patients with diabetic nephropathy. Am J Kidney Dis 2001;38:S161S164.

21 Chang TJ, Lei HH, Yeh JI, Chiu KC, Lee KCh, Chen MCh, Tai TY, Chuang LM: Vitamin D receptor gene polymorphisms influence susceptibility to type 1 diabetes mellitus in the Taiwanese population. Clin Endocrinol 2000;52:575-580.

22 Goswami R, Mohapatra T, Gupta N, Rani R, Tomar N, Dikshit A, Sharma R: Parathyroid Hormone Gene Polymorphism and Sporadic Idiopathic Hypoparathyroidism. J Clin Endocrinol Metab 2004;89:4840-4845.

23 Nagaba Y, Heishi M, Tazawa H, Tsukamoto Y, Kobayashi Y: Vitamin D Receptor Gene Polymorphisms Affect Secondary Hyperparathyroidism in Hemodialyzed Patients. Am J Kidney Dis 1998;32:464-496.

24 Taverna MJ, Selam JL, Slama G: Association between a protein polymorphism in the start codon of the vitamin D receptor gene and severe diabetic retinopathy in C-peptide-negative type 1 diabetes. 2005;90:4803-4808.

25 Kavanagh D, McKay GJ, Patterson CC, McKnight AJ, Maxwell AP, Savage DA; Warren 3/UK GoKinD Study Group: Association analysis of Notch pathway signalling genes in diabetic nephropathy. Diabetologia 2011;54:334-338.

-26 Amato M, Pacini S, Aterini S, Punzi T, Gulisano M, Ruggiero M: Iron indices and vitamin D receptor polymorphisms in hemodialysis patients. Adv Chronic Kidney Dis 2008;15:186-190.

27 Vigo Gago E, Cadarso.Suárez Cm Perez-Fernandez R, Romeo Burgos R, Devesa Mugica J, Segura Iglesias C: Association between vitamin D receptor FokI. Polymorphism and serum parathyroid hormone level in patients with chronic renal failure. J Endocrinol Invest 2005;2:117-121.

28 Dilmec F, Uzer E, Akkafa F, Kose E, van Kuilenburg AB: Detection of VDR gene ApaI and TaqI polymorphisms in patients with type 2 diabetes mellitus using PCR-RFLP method in a Turkish population. J Diabetes Complications 201;24:186-191.

29 Oh JY, Barrett-Connor E: Association between vitamin D receptor polymorphism and type 2 diabetes or metabolic syndrome in community-dwelling older adults: the Rancho Bernardo Study. Metabolism 2002;51:356-359.

30 Pani MA, Knapp M, Donner H, Braun J, Baur MP, Usade HK, Badenhoop K: Vitamin D receptor allele combinations influence genetic susceptibility to type 1 diabetes in Germans. Diabetes 2000;49:504-507. 


\section{Kidney \\ Blood Pressure Research}

Kidney Blood Press Res 2012;36:1-9

\begin{tabular}{l|l} 
DOI: $10.1159 / 000339021$ & C) 2012 S. Karger AG, Basel
\end{tabular}

Published online: June 18, 2012

www.karger.com/kbr

9

31 Chang TJ, Lei HH, Yeh JI, Chiu KC, Lee KC, Chen MC, Tai TY, Chuang LM: Vitamin D receptor gene polymorphisms influence susceptibility to type 1 diabetes mellitus in the Taiwanese population. Clin Endocrinol (Oxf) 2000;52:575-580.

-32 Nejentsev S, Godfrey L, Snook H, Rance H, Nutland S, Walker NM, Lam AC, Guja C, Ionescu-Tirgoviste C, Undlien DE, Rønningen KS, Tuomilehto-Wolf E, Tuomilehto J, Newport MJ, Clayton DG, Todd JA: Comparative high-resolution analysis of linkage disequilibrium and tag single nucleotide polymorphisms between populations in the vitamin D receptor gene. Hum Mol Genet 2004;13:1633-1639.

-33 Turpeinen H, Hermann R, Vaara S, Laine AP, Simell O, Knip M, Veijola R, Ilonen J: Vitamin D receptor polymorphisms: no association with type 1 diabetes in the Finnish population. Eur J Endocrinol 2003;149:591-596.

-34 Škrabič V, Zemunik T, Šitum M, Terzič J: Vitamin D receptor polymorphism and susceptibility to type 1 diabetes in the Dalmatian population. Diabetes Research and Clinical Practice 2003;59:31-35.

35 Dogan I, Onen HI,Yurdakul AS, Konac E, Ozturk C, Varol A, Ekmekci A: Polymorphisms in the vitamin D receptor gene and risk of lung cancer. Med Sci Monitor 2009;15:232-242.

-36 Gunes S, Sumer AP, Keles GC, Kara N, Koprulu H, Bagci H, Bek Y: Analysis of vitamin D receptor polymorphisms in patients with chronic periodontitis. Indian J Med Res 2008;127:58-64.

-37 Ogunkolade BW, Boucher BJ, Prahl JM, Bustin SA, Burrin JM, Noonan K, North BV, Mannan N, McDermott MF, DeLuca HF, Hitman GA: Vitamin D receptor (VDR) mRNA and VDR protein levels in relation to vitamin D status, insulin secretory capacity, and VDR genotype in Bangladeshi Asians. Diabetes 2002;51:22942300. 